\title{
Література
}

1. Гальтон Ф. Наследственность таланта: Законы и последствия / Ф. Гальтон. - М. : Мысль, 1996. - 296 с. 2. Дружинин В. Н. Психология общих способностей / В. Н. Дружинин. - СанктПетербург : Питер, 1999. - 368 с. 3. Леонтьев А. Н. Биологическое и социальное в психике человека // Проблемы развития психики. - М. : Изд-во МГУ, 1981. - С. 196-219. 4. Платонов К К. Проблемы способностей / К К. Платонов. - М. : Наука, 1972. - 310 с. 5. Теплов Б. М. Способности и одаренность // Б. М. Теплов. Проблемы индивидуальных различий. - М. : Изд-во АПН РСФСР, 1961. - С. 9-39. 6. Ярошевский М. Г. История психологи / М. Г. Ярошевский. - [5-е изд.]. - М. : Мысль, 1985. -575с.

УДК 372.41

О. А. Павлик, кандидат пед. наук, доцент, Криворізький педагогічний інститут ДВНЗ «Криворізький начіональний університет»

\section{ФОРМУВАННЯ ТВОРЧОЇ ОСОБИСТОСТІ МОЛОДШОГО ШКОЛЯРА ЗАСОБАМИ ТРВЗ-ТЕХНОЛОГІЇ НА УРОКАХ НАВЧАННЯ ГРАМОТИ}

Павлик О. А. Формування творчої особистості молодшого школяра засобами ТРВЗ-технології на уроках навчання грамоти.

У статті розглядається проблема формування творчої особистості першокласника, з'ясовується сутність основних понять, окреслюються методи і прийоми ТРВЗ в аспекті досліджуваної проблеми.

Ключові слова: творчість, творча особистість, ТРВЗ-технологія, методи і прийоми розвитку творчих якостей.

Павлик Е.А. Формирование творческой личности младшего школьника средствами ТРВ3технологии на уроках обучения грамоте.

В статье рассматривается проблема формирования творческой личности первоклассника, раскрывается сущность основных понятий, описываются методы и приемы ТРВ3 в аспекте исследуемой проблемы.

Ключевые слова: творчество, творческая личность, ТРВ3 - технология, методы и приемы развития творческих качеств.

Pavlyk O. A. Formation of the creative person Junior schoolboy means TPB3-technologies at the lessons of the literacy training.

In the article is considered the problem of formation of the creative person of the first-grader, it turns out the essence of the main concepts, describes the methods and techniques TRVZ in the aspect of the problem under investigation.

Key words: creativity, creative personality, TRVZ - technology, methods and techniques for developing creative qualities.

«...Система освіти має виховувати, а не вбивати креативність та творчі здібності... »

(Сер Кен-Робінсон).

Сучасний етап розвитку українського суспільства потребує якісно нового рівня освіти, підвищення іiі конкурентоспроможності, розв'язання стратегічних завдань, пов'язаних 3 новими економічними і соціокультурними умовами 3 огляду на інтеграцію України у світовий освітній простір. У зв'язку з цим оновлений Державний стандарт початкової загальної освіти грунтується на засадах особистісно зорієнтованого і компетентнісного підходів, що зумовлює чітке визначення результативної складової засвоєння змісту початкової загальної освіти.

Відповідно до нового Державного стандарту початкової загальної освіти одним із стратегічних завдань початкової школи $є$ формування освіченої, творчої особистості, здатної діяти в нових соціально-економічних умовах. Розв'язання цього завдання передбачає оновлення змісту й тактики здійснення навчального процесу, спрямованого на 
розвиток особистості учнів, їх креативності. Компетентнісний підхід вимагає від учнів не лише певних знань, умінь і навичок, а й здатності до розв'язання винахідницьких завдань. Проте на шляху виникає багато суперечностей, зокрема щодо недостатньої підготовленості вчителя й учнів до креативної діяльності, домінування педагогічних стереотипів і необхідності щоденно долати різноманітні навчальні та життєві проблеми, котрі вимагають неординарності у ставленні до різних аспектів буття, спеціальних умінь долати психологічну інерцію.

Як свідчить аналіз наукової літератури, теоретичні положення $з$ проблеми розвитку творчої особистості висвітлено у працях О. Лука, Р. Немова, Я. Пономарьова, С. Рубінштейна, Б. Теплова. Педагогічний аспект окресленої проблеми досліджували В. Левін, І. Лернер, А. Мелік-Пашаєв та інші. Особливості навчання грамоти на сучасному етапі досліджують М. Вашуленко, О. Прищепа, М. Захарійчук, В. Науменко. ТРВ3 як технологію творчості, розвитку творчого мислення дітей різного віку, розроблену Г. Альтшуллером, досліджують А. Гін, Т. Сидорчук, В. Телячук, О. Лесіна та інші. Проте ми не виявили спеціальних досліджень, присвячених проблемі розвитку креативності на уроках навчання грамоти засобами ТРВЗ.

Метою статmі є визначення найбільш оптимальних засобів ТРВЗ для формування творчої особистості молодших школярів у період навчання грамоти.

На думку дослідників, творча особистість - це такий тип особистості, для якого характерна стійка, високого рівня спрямованість на творчість, мотиваційно-творча активність, що виявляється в органічній єдності з високим рівнем творчих здібностей, які дозволять ій досягти прогресивних, соціально та особистісно значущих результатів в одному або кількох видах діяльності [3, с. 15].

В. Сухомлинський визначав творчість як «бачення людиною свого внутрішнього світу, передусім свого розуму, свого напруження інтелектуальних сил, розуміння і творення краси внаслідок праці, своїх зусиль» [4, с. 155]. За словами науковця, не важливо, що маленька дитина повторює те, що було вже зроблено, створено іншими людьми, головне те, що це діяння - плід іiї власних розумових зусиль - вона творець; іiі розумова діяльність - творчість.

Творчість - норма дитячого розвитку, органічно притаманна дитині з раннього віку. Кожному періоду властиві власні домінанти творчої діяльності, які забезпечують особистісне становлення кожної дитини і є засобом розвитку дошкільника в молодшого школяра. Творчість може бути поєднанням нових елементів із минулим досвідом, на грунті чого з'являються нові ідеї та концепції. Основний елемент творчості - це можливість вийти за межі стереотипів та консервативних правил. Творчість людини - це не тільки досягнення певного результату, а й створення суб' єктивного творчого досвіду, що має велике значення в дитячій освіті. Він дозволяє виявити оригінальність кожній окремій дитині.

Формування творчої особистості - це динамічний процес, що відбувається під впливом різноманітних чинників, серед яких важливе місце посідає творча діяльність і особистість учителя. Співпраця між учнями та вчителем, залучення батьків до організації і проведення різних форм роботи - запорука успішної діяльності [2, с. 22].

Добираючи засоби для формування творчої особистості, необхідно враховувати те, що основне завдання - це розвиток творчого потенціалу учня. На це і спрямована технологія творчості ТРВ3. Її метою $є$ формування логічного мислення i виховання творчої особистості, підготовленої до розв'язування складних проблем у різних сферах діяльності. У педагога, який використовує теорію, діти навчаються із захопленням, без перевантажень засвоюють нові знання, розвивають мовлення й мислення. Отже, ТРВЗтехнологія - це унікальний інструмент для пошуку нових оригінальних ідей; виявлення і вирішення багатьох творчих проблем. При цьому можна виокремити основні функції TPB3:

- розв'язання творчих і винахідницьких завдань будь-якої складності і спрямованості 
без оцінювання варіантів;

- прогнозування розвитку технічних систем (ТC) та отримання перспективних рішень (зокрема і принципово нових);

- розвиток якостей творчої особистості.

Причому для розвитку творчих якостей особистості в ТРВ3-технології використовуються методи розвитку творчої уяви; теорія розвитку творчої особистості; теорія розвитку творчих колективів [5, с. 12].

Сучасна ТРВ3-педагогіка включає в себе курси, розраховані на вікові групи від дошкільнят до студентів і дорослих фахівців. Особливістю роботи 3 кожною віковою групою є вибір об'єктів винахідницької діяльності відповідно до віку. Так, дошкільнята та молодші школярі винаходять іграшки, загадки, прислів'я, рухливі ігри тощо. До основних принципів побудови занять з використанням ТРВЗ-технології в початковій школі можна віднести: мінімум повідомлення інформації, максимум міркувань; оптимальну форму організації обговорення проблемних ситуацій - мозковий штурм; системний підхід (все в світі взаємопов'язане, і будь-яке явище має розглядатися в розвитку); включення в процесі пізнання всіх доступних для дитини розумових операцій i засобів сприйняття (аналізаторів, причинно-наслідкових висновків i висновків, зроблених самостійно; предметно-схематичної наочності); обов'язкову активізацію творчої уяви.

Отже, ТРВ3-технологія, з одного боку, - цікава гра, з іншого - розвиток розумової активності дитини через творчість, яка дає дитині: можливість виявити себе; прагнення отримувати нову інформацію про навколишній світ; розвиває потребу в пізнавальній діяльності; дає можливість творити; сприяє розвитку аналітичних здібностей; сприяє формуванню вміння розвивати і доводити свою точку зору [1].

Використання цієї технології дозволяє суттєво підвищити вірогідність розв'язання деяких класів нестандартних (творчих, креативних) задач [2, с. 1].

Отже, ТРВ3 - це складний, але цікавий процес оволодіння знаннями. Він вимагає від учителя підготовки, оскільки уроки носять яскраво виражений діалоговий характер, а для активної участі дітей в обговоренні досліджуваного матеріалу вчитель повинен так налаштувати дітей, щоб вони самі могли знайти необхідні аргументи на захист правильної версії, тобто самостійно проаналізувати та узагальнити матеріал.

Під час проведення уроків можна застосовувати такі форми роботи 3 дітьми: бесіду, сюжетно-рольові та дидактичні ігри, прослуховування музики, інсценування та моделювання ситуацій, виконання практичних робіт. Важливу роль виконують схеми, таблиці, умовні позначення та інші способи подачі інформації. Використовуються казки, загадки, прислів'я, твори дитячих письменників. Важливу роль відіграють вірші, складені так, щоб мораль, а також висновок не були на передньому плані, а містилися в середині ситуації. Майстерність вчителя полягає в тому, щоб дати можливість дітям самим побачити цю мораль і зробити відповідний висновок.

Розглянемо приклади використання ТРВЗ-технології у період навчання грамоти. Для розвитку творчої уяви дітей на уроках навчання грамоти можна використати прийом «Фантазери». Особливістю цього прийому є те, що його можна використовувати як у букварний, так і в добукварний період навчання грамоти.

Наприклад, під час вивчення теми «Мої книжки» можна учням запропонувати після опрацювання тексту «Казкар» за О. Дроздом таке завдання: «Уявіть, що було б, коли б ви стали казкарем-чарівником »

Тема «Звук [а], позначення його буквами Аа». Застосовуємо метод фокальних об'єктів, який полягає в перенесенні властивостей одного предмета на інший. Використовуючи цей метод, необхідно дотримуватись алгоритму роботи. Спочатку необхідно довільно дібрати до поданого слова-помічники, потім визначити їх ознаки, які будуть незвичайними для ключового слова. При цьому необхідно пояснити, за яких умов цей предмет може набувати таких властивостей.

Продемонструємо це на прикладі: слово у фокусі підбираємо відповідно до теми - 
акула. Слова-помічники: кульки - повітряні, різнокольорові, легкі; потяг - пасажсирський, яскравий, веселий. Завдання: скласти казку про акулу, використовуючи знайдені словапомічники.

«Жила собі в морських глибинах тітонька акула. Вона була дуже доброю $і$ знала всіх малят в океані. I ось настав день ї̈ народження. Акула вдягла гарненьку шкіру, сіла в яскравий пасажсирський потяг, який піднімав їй настрій. Вона так швидко їхала, щуо ї̈ плавник аж винирював із глибин. Тітонька акула приїхала до своїх друзів, які вітали ї зі святом. Вона пригостила їх смачним морозивом з водоростей, а вони в свою чергу заспівали веселих пісень і подарували їй легкі різнокольорові кульки».

Тема «Звук [y], позначення його буквами Уу». Використаємо прийом «Біном фантазії». Пропонуємо учням придумати фантастичну історію, у якій всі слова починатимуться на «у». Проте спочатку першокласники мають пригадати і дібрати такі слова 3 початковим [y], запам'ятати їх, щоб згодом пов'язати за змістом і використати у власному зв'язному висловлюванні.

Отже, ТРВЗ-технологія має багато позитивних сторін: у дітей збагачується коло уявлень, зростає словниковий запас, розвиваються творчі здібності. ТРВ3 допомагає формувати логічне мислення, сприяє подоланню сором'язливості, замкнутості, остраху; маленька людина вчиться відстоювати свою точку зору, а потрапляючи у важкі ситуації, самостійно знаходити оригінальні рішення; сприяє розвитку наочно-образного, причинового, евристичного мислення, пам'яті, уяви, впливає на інші психічні процеси. Окрім того, використання засобів ТРВ3 на уроках навчання грамоти дозволяє формувати комунікативну компетенцію, вміння бачити, аналізувати і розв'язувати навчальні та життєві проблеми самостійно.

\section{Література}

1. Введение в ТРИЗ. Основные понятия и подходы: [Электронный ресурс]. - Режим доступа: http://www.triz-chance.ru/e-books.html. 2. Демчук Л. В. Виховання творчої особистості / Л. В. Демчук // Психологічна газета. - 2007. - № 16. - С. 22-31. 3. Рибалка В. В. Поняття про творчість, творчу особистість та особистісний підхід до вивчення і розвитку творчого потенціалу молоді / В. В. Рибалка // Психологія розвитку творчої особистості. - К., 1995. - С. 5-24. 4. Сухомлинский В. А. Сердце отдаю детям / В. А. Сухомлинский. - 2-е изд. - К. : Рад. школа, 1972. - 244 с. 5. Телячук В. П. Сходинками творчості. Методика ТРВ3 у початковій школі / В. П. Телячук, О. В. Лесіна - К., Основа, 2007. - 112 с.

\section{ФОРМУВАННЯ ЧУТТЕВОЇ КУЛЬТУРИ УЧНІВ ОСНОВНОЇ ШКОЛИ У ПРОЦЕСІ ВИВЧЕННЯ ХУДОЖНЬОЇ ЛІТЕРАТУРИ}

Паламар С. П. Формування чуттєвої культури учнів основної школи у процесі вивчення художньої літератури.

У статті окреслено чинники, що впливають на формування та збагачення чуттєвої культури учнів основної школи; проаналізовано значення у цьому процесі вивчення художньої літератури. Доведено взаємозв'язок сформованості чуттєвої культури учнів основної школи з рівнем розвитку художнього виховання. Уміння здіснювати літературний аналіз художнього тексту віднесено до структури читацької компетентності учнів основної школи.

Ключові слова: чуттєва культура, учні основної школи, вивчення художньої літератури, читацька компетентність.

Паламар С. П. Формирование чувственной культуры учащихся основной школы в процес се изучения художественной литературы. 